\title{
FIRM SPECIFIC DETERMINANTS OF MARKUP - THE CASE OF SLOVENIAN MANUFACTURING FIRMS
}

\author{
Nina Ponikvar ${ }^{1}$, Melita Rant ${ }^{2}$ \\ Faculty of Economics, University of Ljubljana. \\ Kardeljeva pl. 17, 1000 Ljubljana, Slovenia \\ Phone: +368015892 400, Fax: + 38615892698 \\ le-mail:nina.ponikvar@ef.uni-lj.si; \\ 2 e-mail:melita.rant@ef.uni-lj.si \\ Received 4 April 2007; accepted 20 March 2007
}

\begin{abstract}
Investigations of firms' pricing decisions and performances have been twofold. While within the industrial organisation framework stress is placed on industry-specific factors and the market power of firms within industries, various organisational theories emphasise the role of 'soft' factors in the determination of firms' performance. The main thesis of our paper is that the size of a firm's markup can mostly be explained by the firm's productivity, capital and labour costs, as well as the firm's market power and organisational structure characteristics, when the external environment and industry membership is controlled for. Our objective is thus to explain firm-level markups by a set of firm-specific factors. The empirical analysis of markup determinants is based on a sample of Slovenian manufacturing firms (NACE 15-37) in the 1994-2003 period, applying panel data regression GLS model and ANOVA analyses. We find that, besides market share and cost factors, organisational structure change occurring after some threshold significantly increases markups.
\end{abstract}

Keywords: firm-specific factors, industry, manufacturing firms, markup, organisational change, Slovenia.

\section{Introduction}

Investigations of firms' pricing decisions and performances have been twofold. Although most authors agree that a firm's performance, reflected through the markups/margins it has achieved, results from firm-specific, industry-specific and factors of general economic environment, the main point of their disagreement involves the importance of each of these three sets of determinants. While within the industrial organisation framework the stress is placed on industry-specific factors and the market power of firms within industries, various organisational theories emphasise the role of 'soft' factors in the determination of firms' performances. The aim of our paper is to recognise the set of firm-specific factors, influencing a firm's performance, measured by markup size. The empirical study is founded on the findings of previous empirical work. The main contribution of our approach is, however, to jointly examine market factors, cost factors and 'soft' firm-specific factors.

\section{Theoretical and empirical literature overview}

The theory on the determinants of firm performance has evolved from two streams which originate from quite diverse research fields; industrial organisation and organisational theory. While economists within industrial organisation primarily emphasise the industry membership of a firm as a key determinant of the firm's performance, organisational theorists stress business strategy and organisational structure as the main drivers of a firm's success. Over time both of these streams have moved close to each other since both economists and organisational theorists have acknowledged the importance of both industry- and firm-specific factors due to their mutual interdependence.

Most industrial organisation research on firms' performance and markups derives from three different traditions. In the classical tradition, following the structure-conduct-performance (SCP) paradigm and Bain $(1951,1956)$ industrial economists treated the industry or market as the unit of study. Differences among firms were assumed transitory or unimportant unless they were based on scale economies, which were gen- 
erally found to be insubstantial. Industry's profitability was generally assumed to be primarily determined by the ability of established firms to restrict rivalry among themselves and the protection afforded them by barriers to entry. A central proposition in virtually all the classical work was that an increase in seller concentration tends to raise industry-wide markups and profitability by facilitating collusion. Most classical studies thus included concentration among the independent variables in regression analyses of industry average rates of return and most published studies reported the coefficient on concentration as being positive and significant (Scherer and Ross, 1990).

An anticlassical, revisionist view of industrial economics emerged in the 1970s and was initially explicitly articulated by Harold Demsetz (1973), while the related formal models were first developed by Jovanovic (1982). In the simplest model consistent with this view, all markets are, at least approximately, competitive and scale economies are absent or negligible. The key assumption is that within at least some industries there are persistent differences in efficiencies among sellers. Because more efficient enterprises tend both to grow at the expense of their rivals and to have higher markups due to lower costs, these differences tend to induce a positive intra-industry correlation between market share and markups even in the absence of scale economies. Moreover, the more important are efficiency differences in any industry, the less equal are the market shares, the higher is the market concentration and the higher are the markups and profits of leading firms and consequently the higher is the industry average markup. This model thus predicts a positive correlation between concentration and markup at the industry level even though, by assumption, concentration does not facilitate the exercise of market power. At the firm or business unit level, the revisionist view implies that market share should appear as the primary determinant of profitability while market concentration should have no impact.

A third tradition, which is often called the managerial tradition (Schmalensee, 1985) has yet another set of implications for firm profitability and markup level. Business schools and management consultants exist because it is widely believed that some firms are better managed than others and that one can learn important management skills that are not industry-specific. In one of the first econometric studies within the managerial tradition, Mueller (1977) reported on the existence of a substantial, long-lived difference in firm profitability and found that industry effects, when compared to firm effects, are relatively unimportant in general.

Industrial economists following Mason and Bain have run innumerable tests of the relationship between various market structural variables and various dimensions of performance. The most popular activity has been to relate profit rates, variously defined, to measures of concentration and barriers to entry. In 1976 Cowling and Waterson developed a version of a well-known homogenous product oligopoly model, which became a base for a great deal of latter empirical work on the determinants of market performance. Improvements to the Cowling-Waterson model followed by recognising the simultaneous determination of the variables from the Structure, Conduct and Performance elements of the SCP paradigm (Clarke and Davies, 1982) and by introducing models based on panel data (Domowitz, Hubbard and Petersen, 1986). Since the 1990s estimations of the markup equations have mainly been based on firm-level panel datasets (e.g. Machin and Van Reenen, 1993; Lima and Resende, 2004). Methodologically, the markup models retained the characteristics of the industry-level studies. Nevertheless, the use of firm-level data allowed researchers to take firm-diversity within industries into account and to incorporate the firm-specific variables introduced by the revisionist and managerial traditions into the profitability models. Firm-level panel data have therefore given researchers the opportunity to study a firm's performance instead of market performance. Since then, although firm-heterogeneity within industries has been acknowledged within the industrial organisation theory the issue has been dealt with by adopting special econometric techniques to eliminate so-called 'individual effects' and/ or by specifying dynamic panel models through the inclusion of the lagged dependent variable to account for all 'immeasurable' or 'soft' strategic characteristics of firms. Competitive and technological factors and their influence on a firm's performance have therefore remained the true subject of interest when firms' heterogeneity is accounted for.

On the other hand, a focus on intra-industry performance differentials has emerged in studies by Caves and Porter (1977) and Porter (1979), following ideas regarding the importance of strategic groups. Strategic groups are believed to follow similar strategies and, due to their structural similarity, to respond in the same way to disturbances within their industry. In contrast to the traditional industrial organisation assumption of homogeneity in firm performance, the concept of strategic groups predicts that performance differences would exist between strategic groups due to mobility barriers. This thesis was investigated and confirmed by a variety of empirical studies (see the overview in Lewin et al., 2004 and Barney and Hesterly, 2006).

Both the revisionist and managerial traditions within 
industrial organisation acknowledge the importance of differences among firms within industries, which form a firm-specific competitive (dis)advantage. The latter is also the main research subject of various organisational theories.

Penrose (1959) was one of the first to frame the idea of the heterogeneity of firms, based on the resource-based view on firms. According to the resource-based view a firm is described as a bundle of resources. Among these resources, those that are valuable, rare, imperfectly imitable and strategically unique, with no substitutes, are believed to provide a sustainable competitive advantage (Barney, 1991). In this view, resources are considered valuable if they enable a firm to increase its efficiency and effectiveness, and rare if they allow a firm to implement a strategy that cannot be simultaneously implemented by other firms. Further, rare and valuable resources are a source of sustained competitive advantage only if they are simultaneously inimitable by competitors and immobile, thereby making it impossible for other firms to obtain them (Peteraf, 1993). Resources are generally considered to be inimitable if (a) they are embedded in firm history, (b) their relationship to performance outcomes is causally ambiguous (Lippman and Rumelt, 1982), or (c) they are socially complex (Dierickx and Cool, 1989). Accordingly, inimitability is closely related to 'soft' organisational factors such as organisational structure and culture (Barney and Hesterly, 2006). Limits on resource mobility may similarly arise from a number of factors. The main objective of empirical research within the resource-based view is therefore to identify the set of factors that builds a firm's sustainable competitive advantage. Among these factors studies emphasise the timing of an entry to new markets and a first-mover advantage (Mahoney and Pandian, 1992; Lieberman and Montgomery, 1998), diversification (Barney, 1991; Chang, 1996), mergers and acquisitions (Sharma and Kesner, 1996; Robins and Wiersema, 1995) and the social complexity of firm-specific resources and competencies (Dierickx and Cool, 1989). The latter study is closely related to contingency theory, which is purely empirical and addresses the relationship between a firm's organisation, local and macro environment and a firm's performance. The central assumption of contingency theory is that organisations are able to adapt to the environment through organisational change, which includes organisational strategies and structures. More than one equally suitable organisational solution exists for a specific environmental state (equifinality of organisational solutions) (Drazin, Van de Ven, 1985; Gresov, 1989). Typical contingency research has been differentiated in terms of the types of contingency fac- tors being investigated, such as strategy (Chandler, 1962), technology (Woodward, 2004) or environmental change (Burn and Stalker, 1969).

While the main disadvantage of the traditional industrial organisation theory and empirical studies is the insufficient consideration of firm diversity and/or the lack of its detailed study, the focus of organisational theories and empirical investigations is above all on explaining firms' diversity. Our main thesis, which we seek to advocate in this paper, is therefore, that only when the field of industrial organisation and the framework of organisational theories are brought together can the performance of firms be sufficiently explained by accounting for the industry membership of the firm and firm-specific factors.

\section{Data}

The empirical analysis of markup determinants is based on a sample of Slovenian manufacturing firms (NACE 15-37) in the 1994-2003 period. The dataset used is based upon two data sources. One is the database of companies' financial statements collected by the Agency of the Republic of Slovenia for Public Legal Records and Related Services (APLR), supplemented by data on firms' legal and organisational forms, the formation and termination of operations from the Business Register of Slovenia. The other is a questionnaire about organisational and network structure changes sent to the management of all Slovenian companies with more than 50 employees. In the questionnaire 17 different organisational structures and six different network structure adaptations were studied. All nominal data are in Slovenian tolars and the original data were deflated using appropriate deflators. Data related to sales, costs and assets were deflated with the producer price index (on a 2-digit NACE classification level), while the remaining nominal data were deflated with the consumer price index. The industry membership of firms is defined on the 5-digit NACE classification of activities.

\section{Model and methodology}

We follow the model first introduced by Schmalensee (1985) and followed by Rumelt (1991) as:

$y_{i j t}=\alpha+\gamma_{j}+\delta_{t}+\eta_{j t}+\beta X_{i j t}+u_{i j t}$,

where a firm's performance $y_{i j t}$ is modelled as a function of the firm's $i$ contemporaneous characteristics $X_{i j t}$ with unknown weights $\beta, \alpha$ is a constant, $\gamma_{j}$ are industry effects, $\delta_{t}$ are time-specific effects, $\eta_{j t}$ are industry-year interaction effects and $u_{i j t}$ is the error. 
The main thesis of our paper is that the size of a firm's markup can be explained for the most part by a firm's productivity, capital and labour costs, as well as a firm's market power and organisational characteristics, when the external environment and industry membership are controlled for. Our objective is thus to explain firm-level markups through a set of firm-specific factors. According to our thesis, three sets of firm-level characteristics significantly influence a firm's markup decisions: (a) market power; (b) technological and cost factors; and (c) organisational structure characteristics.

The simple oligopoly model of firm performance implies a positive relationship between market share and markup size. An intuitive interpretation is that a firm with a greater market share is able to charge higher prices (and therefore achieve a superior level of markup) due to its higher markup power and larger opportunities for collusion. However, an opposing hypothesis is that, as market share increases, competitive pressures are weakened, suggesting that profitability (and markups) is lower because the incentive to minimise costs is no longer important. Equally, it is possible that firms with lower market shares are smaller and more flexible, allowing for lower costs and higher profitability. The market power of a firm is thus hypothesised to increase markups due to the bigger opportunities for collusion and/or due to the higher efficiency of firms (Bain, 1956; Demsetz, 1973).

The price set for a particular product by a firm is the sum of the unit production cost and the markup. We thus expect that higher production factor costs leading to higher unit costs do not always result in higher prices. How much the higher costs will be spilled over into higher prices depends on the strength of the competition within a particular industry. When the competition among firms within the same industry is strong enough, it is able to prevent the complete transformation of the higher unit cost into higher final product prices. In such cases, higher production costs lead to lower markups. At the same time, we expect more productive firms to charge higher markups due to lower unit costs at given prices of inputs.

When studying complex multiple interactions between (organisational and environmental) changes, performance benefits of any change are dependent upon the nature of other potentially complementary changes (Whittington et al., 1999). The complementarities notion, based on complexity theory, warns strongly of a possible J-curve relationship between change and performance, with partial implementation potentially worse than the starting point (Pettigrew, 1995). In other words, organisational change has to be congru- ent and extensive enough to influence the performance in a positive manner. We thus expect that after some threshold level an organisational change improves a firm's performance.

\section{Variable definitions and measurement construct}

A firm's performance is measured by markup as defined in works by Kalecki (1954). By using sales, inventories and costs, Kalecki's version of the markup definition as the ratio between price and the unit direct cost of production can be constructed. When multiplied by quantity produced, markup is thus defined as the ratio between a firm's revenues and direct cost:

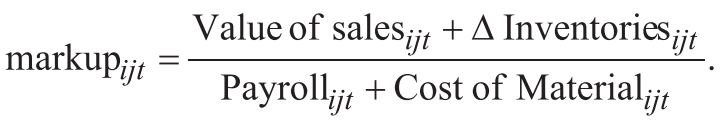

Market share $\left(m s_{i j t}\right)$ is defined as the share of a firm's domestic market sales in the 5-digit NACE industry annual sales (home sales of domestic firms in an industry plus imports in industry $j$ ).

$M S_{i j t}=\frac{\text { Domestic Sales }_{i j t}}{\text { Domestic Sales of domestic firms }_{j t}+\text { Imports }_{j t}} \cdot(3)$

To allow for the possibility of a U-shaped relationship between markup and market share, our empirical specification will include both market share and the square of market share as explanatory variables. Labour productivity $\left(\operatorname{lprod}_{i j t}\right)$ is defined as value added per employee. The price of labour $\left(w_{i j t}\right)$ is calculated by dividing annual gross wages by the average number of employees for each firm. The price of capital $\left(r_{i j t}\right)$ is calculated as the difference between total cost and the cost of labour relative to the sum of fixed assets and inventory. Export orientation (exor ${ }_{i j t}$ ) is presented by the share of a firm's revenues from exports in the total annual sales of the firm. Empirical studies that use the markup (or PCM) as the dependent variable commonly include capital intensity $\left(\mathrm{ki}_{i j t}\right)$ as an explanatory variable (Domowitz, Hubbard and Petersen, 1986; Feeny, Harris and Rogers, 2005) for two reasons: first, because the markup is usually calculated without taking into account the cost of capital in production, and the capital intensity measure is included to capture this effect and, second, to control for differences in the capital intensity of production among firms. Capital intensity is measured as the ratio of a firm's total fixed assets to the number of the firm's employees.

Organisational structure adaptations $\left(\operatorname{org}_{i j}\right)$ include all contemporary organisational structure changes that 
lead to the firm's more responsive and adaptive performance. More specifically, they encompass flattening and downsizing; re-engineering the business processes; subcontracting and outsourcing of non-core activities; creating multifunctional project teams; empowering employees; increasing workforce flexibility (multiskilled workers); expanding the externalised workforce (temporary workers); replacing highly specialised machinery for flexible manufacturing systems; developing multipurpose information systems etc. (Volberda, 1998).

These adaptations, presented in Table 1, can be implemented in one or more business fields/functions: sales, production, purchasing, finance, staffing, and support function (information-processing, planning and control etc). The extent of adaptation was assessed according to number of fields a specific type of organisational adaptations was implemented. In the event a specific organisational structure change was not implemented, it was assessed with 1 . If it was implemented in only one field (i.e. production) it was assessed with 2 . If it was implemented in all crucial business fields/functions it was assessed with 7 . The average extent of all seventeen organisational structure adaptations gave the extent of organisational structure adaptations $\left(\operatorname{org}_{i j}\right)$. The presented organisational structure measurement constructs builds on the logic of a seven-point Likert scale.

To control for the industry-effects, time-specific effects and industry-time interaction effects, throughout our sample period we include year dummies (year), industry dummies on the 2-digit NACE level (industry) and a set of dummy variables on interactions between industries and time (industry*year). The set of industry dummy variables is defined, however, on the 2-digit level of NACE classification due to the small sample size. As a result we estimate the model (4) with the following specification, where subscript $i$ refers to a firm, $j$ - to industries according to the 5-digit NACE classification of industries and $t-$ to a particular year, respectively.

$$
\begin{aligned}
& \operatorname{markup}_{i j t}=\alpha+\beta_{1}+\beta_{2} \mathrm{MS}_{i j t}+\beta_{3} \mathrm{MSsq}_{i j t}+\beta_{4} \operatorname{exor}_{i j t}+ \\
& \beta_{5} \operatorname{size}_{i j t}+\beta_{6} \operatorname{lprod}_{i j t}+\beta_{7} \mathrm{w}_{i j t}+\beta_{8} \mathrm{r}_{i j t}+\beta_{9} \mathrm{ki}_{i j t}+\beta_{10} \operatorname{org}_{i j t}+ \\
& \beta_{11} \text { industry }+\beta_{12} \text { year }+\beta_{13} \text { industry*year }+\mathrm{u}_{i j t} .
\end{aligned}
$$

Table 1. Organisational structure adaptations indicator

\begin{tabular}{|l|l|l|l|l|l|l|}
\hline \multicolumn{1}{|c|}{ Indicators } & Product & Sales & Purchasing & Finance & Staff & Stabs \\
\hline Work process automation & & & & & & \\
\hline Updating information technology & & & & & & \\
\hline Decision-making decentralisation & & & & & & \\
\hline Professionalisation of employees & & & & & & \\
\hline Downsizing & & & & & & \\
\hline Delayering & & & & & & \\
\hline Job enlargement and rotation & & & & & & \\
\hline Team work & & & & & & \\
\hline $\begin{array}{l}\text { Cooperation between different business functions } \\
\text { and professional fields within firm }\end{array}$ & & & & & & \\
\hline Products/services customisation & & & & & & \\
\hline Outsourcing & & & & & & \\
\hline $\begin{array}{l}\text { Binding rewards on individual/collective } \\
\text { outcomes }\end{array}$ & & & & & & \\
\hline Decentralisation of planning activities & & & & & & \\
\hline Adaptation of work descriptions & & & & & & \\
\hline Reorganisations of departments & & & & & & \\
\hline Project work & & & & & & \\
\hline Business process reengineering & & & & & \\
\hline
\end{tabular}

Note: For the validity and reliability of measurement construct, see Rant, 2006. 


\section{Results}

In order to gain insights into the explanatory power of particular regressors, we first test the simple ANOVA models. These models do not account for the panel nature of the dataset but, on the other hand, they give useful information about the simple relations between the variables in the model specification.

ANOVA models show the importance of the industry membership of a firm and the development of its organisational structure for markup size. ANOVA Model 1 indicates that average industry markups statistically significantly differ between industries. Industry membership explains approximately 10 percent of the markup variability. A similar conclusion holds for groups of firms that introduce the same type of organisational structure change (ANOVA Model 3). Organisational structure indirectly incorporates most of the firm-specific factors including the technology used by the firm, the firm's strategy, knowledge of the employees, management style and the firm's size. Therefore, organisational structure is a reasonably good indicator of individual specific effects of a firm which explains 32 percent of the markup variability. Although Model 2 indicates that year does not influence markup levels significantly, Model 6 shows that all three variables, i.e. industry membership, year and organisational structure change, also indicating individual specific effects, statistically significantly explain differences in markup levels of particular firms in the sample and account for 38 percent of the variability of markups (see Table 2).

Table 2. ANOVA models

\begin{tabular}{|c|c|c|c|c|c|c|c|c|}
\hline & Period & Source & SS & $\mathrm{df}$ & MS & $\mathrm{F}$ & Prob $>F$ & $\mathrm{R}^{2}$ adj \\
\hline \multirow{3}{*}{1} & \multirow{3}{*}{$1994-2003$} & Between industries & 1,06338756 & 17 & 0,062552209 & 6,90 & 0,000 & 0,1026 \\
\hline & & Within industries & 7,79662626 & 860 & 0,009065844 & & & \\
\hline & & Total & 8,86001381 & 877 & 0,010102638 & & & \\
\hline \multirow{3}{*}{2} & \multirow{3}{*}{$1994-2003$} & Between years & 0,10488593 & 9 & 0,011653992 & 1,16 & 0,321 & 0,0016 \\
\hline & & Within years & 8,75512788 & 868 & 0,010086553 & & & \\
\hline & & Total & 8,86001381 & 877 & 0,010102638 & & & \\
\hline \multirow{3}{*}{3} & \multirow{3}{*}{$1994-2003$} & Between org & 3,25126357 & 62 & 0,052439735 & 7,62 & 0,000 & 0,3188 \\
\hline & & Within org & 5,60875024 & 815 & 0,006881902 & & & \\
\hline & & Total & 8,86001381 & 877 & 0,010102638 & & & \\
\hline \multirow{5}{*}{4} & \multirow{5}{*}{ 1994-2003 } & Model & 1,1836167 & 26 & 0,045523719 & 5,05 & 0,000 & 0,1071 \\
\hline & & Between industries & 1,07873077 & 17 & 0,063454751 & 7,03 & 0,000 & \\
\hline & & Between years & 0,120229144 & 9 & 0,013358794 & 1,48 & 0,150 & \\
\hline & & $\begin{array}{l}\text { Within industries and } \\
\text { years }\end{array}$ & 7,67639711 & 851 & 0,009020443 & & & \\
\hline & & Total & 8,86001381 & 877 & 0,010102638 & & & \\
\hline \multirow{5}{*}{5} & \multirow{5}{*}{$1994-2003$} & Model & 3,87672631 & 79 & 0,049072485 & 7,86 & 0,000 & 0,3819 \\
\hline & & Between industries & 0,625462742 & 17 & 0,036791926 & 5,89 & 0,000 & \\
\hline & & Between org & 2,81333876 & 62 & 0,045376432 & 7,27 & 0,000 & \\
\hline & & $\begin{array}{l}\text { Within industries and } \\
\text { org }\end{array}$ & 4,9832875 & 798 & 0,006244721 & & & \\
\hline & & Total & 8,86001381 & 877 & 0,010102638 & & & \\
\hline \multirow{6}{*}{6} & \multirow{6}{*}{$1994-2003$} & Model & 4,00817967 & 88 & 0,045547496 & 7,41 & 0,000 & 0,3913 \\
\hline & & Between industries & 0,659327694 & 17 & 0,038783982 & 6,31 & 0,000 & \\
\hline & & Between years & 0,131453357 & 9 & 0,014605929 & 2,38 & 0,012 & \\
\hline & & Between org & 2,82456297 & 62 & 0,045557467 & 7,41 & 0,000 & \\
\hline & & $\begin{array}{l}\text { Within industries, years } \\
\text { and org }\end{array}$ & 4,85183414 & 789 & 0,006149346 & & & \\
\hline & & Total & 8,86001381 & 877 & 0,010102638 & & & \\
\hline
\end{tabular}

Source: APLR and own calculations 
Although ANOVA is a very simple tool it clearly shows how decisions on markups are made at the firm level. The largest share of variance is explained by the firm characteristics (org). After firm-specific characteristics are accounted for, the firm relates its markup decisions to the industrial environment and, finally, takes into account the general economic environment (year). But the latter is not significant when firm and industry specificity is not taken into account.

In order to establish the relative importance of the industry, year and firm-specific factors in markup determination, we use standard panel data estimation techniques to estimate the specified model (4). The results are presented in Table 3.

Table 3. Random effects GLS regression results

\begin{tabular}{|l|c|c|}
\hline Dependent variable: markup & Coefficient & sig. \\
\hline & & \\
\hline $\mathrm{ms}$ & 0.2068198 & 0.068 \\
\hline $\mathrm{mssq}$ & -0.3402827 & 0.079 \\
\hline exor & 0.0136694 & 0.644 \\
\hline size_2 & 0.0241015 & 0.318 \\
\hline size_3 & 0.0242877 & 0.383 \\
\hline lprod & 0.0000924 & 0.000 \\
\hline $\mathrm{w}$ & -0.0001681 & 0.000 \\
\hline $\mathrm{r}$ & -0.0507442 & 0.010 \\
\hline ki & -0.0000068 & 0.032 \\
\hline org & 0.0234988 & 0.017 \\
\hline & & \\
\hline year & incl & \\
\hline industry & incl & \\
\hline year*industry & incl & \\
\hline & & \\
\hline constant & 1.09712 & 0.000 \\
\hline & & \\
\hline number of observations & 316 & \\
\hline number of groups & 103 & \\
\hline Rsq & 0.6796 & \\
\hline (df) Wald $\chi 2$ & $(95) 110538.8$ & 0.000 \\
\hline (df) B-P LM test $\chi 2$ & $(1) 12.42$ & 0.000 \\
\hline (df) Hausman $\chi 2$ & $(18) 23.59$ & 0.1688 \\
\hline
\end{tabular}

Source: APLR and own calculations
The Breusch-Pagan test indicates that the panel data estimation techniques are superior to an ordinary regression model and the Hausman test shows that the random effect model is appropriate ${ }^{1}$. Hausman's test therefore indicates that unexplained individual specific effects are not important after a firm's power, productivity, cost factors and organisational structure adaptation have been accounted for. As mentioned before, the finding that organisational structure change is an appropriate indicator of firm individual effects is again confirmed in the regression model. Further, measuring the firm individual effect with organisational structure change gives us an additional insight into the behaviour of the firm that enabled it a superior performance.

The model as a whole is statistically significant and explains 67 percent of the variability in markups. Although the majority of industrial organisation studies on firm performance emphasise that the estimation of a single equation of performance would suffer from endogeneity bias (Hay and Morris, 1991; Martin, 1993), the Davidson-MacKinnon test of endogeneity does not confirm the presence of endogeneity bias. The estimated value for the F-test is smaller than the theoretical value $(F(1.41)=2.15$, Prob $>F=0.1498)$. We thus apply a single equation of random effect regression model. The model specification covers all three main groups of markup determinants: firm characteristics, market/industry membership and general economic environment. Firm determinants are explicitly included and studied within the model. Industry and macro environment are controlled for by sets of dummies. Static characteristics of a particular industry are captured by a set of industry dummy variables. The impact of aggregate economic dynamics is measured by a set of year dummy variables and the industry dynamics is measured by a set of yearindustry interaction dummy variables.

The linear relationship between a firm's market share and the firm's markup is significant ${ }^{2}$ and positive, which is predicted by the simple oligopoly models. Because similar studies (Fenny, Harris and Rogers, 2005; Bennenbroek and Harris, 1995) have provided evidence of a U-shaped relationship between market share and profitability, we also tested the non-linear markup-market share relationship. The coefficient on the square market share is significant and negative. It indicates that market share positively affects markup size but in a decreasing fashion.

\footnotetext{
${ }^{1}$ The Wooldridge test for autocorrelation does not indicate that autocorrelation is an important issue in the specified model $(\mathrm{F}(1,12)=0.097$ with $\mathrm{H}_{0}=$ no first-order autocorrelation, Prob $>\mathrm{F}=0.7607$ ). Similarly, multicollinearity among the regressors is not critical as none of the VIF factors exceeds 6.5. On the other hand, because the modified Wald test indicates that group-wise heteroscedasticity is present in the model, we apply a transformed form of variances.

${ }^{2}$ Due to the small sample size we follow the level of $10 \%$ statistical significance.
} 
A firm's export orientation (the share of foreign sales in total firm sales) has an insignificant although positive effect on markups. The insignificance of the coefficient indicates that a uniform direction of the impact of export orientation on markup level does not exist. Similar findings are reported in Stalhammar (1991). The size of the firm, measured by the number of employees, does not influence the markup size significantly. Obviously, market share takes over the explanatory power of a firm's size. Productivity and cost factors affect the markup size significantly. Labour productivity, measured by value added per employee, has a significant positive effect and cost factors - a significant negative effect on markup size, which is expected. The coefficient on capital intensity is significant and negative, which is not what would be expected by theory. However, because the set of industry-year dummy variables takes over the average characteristics of the technology applied in an industry in a particular year the variability in the capital intensity of production might indicate a firm's underutilisation of production capacities and therefore tendencies to increase capacity utilisation through pricing and markup decisions.

We also tested the influence of the organisational structure change on markup size and it turned out to be insignificant. The result was somehow expected. As suggested by the J-curve concept, the influence of an organisational structure change on a firm's performance is not linear. Accordingly, significant and positive effects of an organisational structure change are only supposed to appear after a certain threshold level of organisational structure change has been passed. We found the threshold to be at the value of 3.5 on a 7-point Likert scale. For firms characterised by the extent of organisational structure change higher than 3.5, the influence of this variable on markup is positive and significant. This confirms the existence of a J-curve. In addition and more importantly, we can infer about the directions of organisational changes that result in higher markups from the measurement construct (e.g. professionalisation of employees, outsourcing of non-core activities, automation of a direct work process, team work and co-operation between business functions, decentralisation of decision-making and planning, introduction of flexible reward systems etc.).

Organisational structure change affects costs as well as revenues (Burton and Obel, 2004). The model explicitly covers the cost side by including labour and capital cost as well as labour productivity. However, even when the cost side of the organisational structure change influences is controlled for, the coefficient of organisational change is still significant and positive. It implicates that organisational structure has a strong influence on a firm's adapting capability, which allows it to better fit in with customers' needs. This results in greater satisfaction of customers and enables firms to charge higher prices and achieve higher markups.

\section{Conclusions}

Our research confirms our main thesis that the size of a firm's markup can mostly be explained by a firm's productivity, capital and labour costs, as well as its market power and organisational characteristics, when the external environment and industry membership are controlled for.

Markup decision-making occurs at the management level. Cost factors on one hand and market price on the other represent an origin of markup determination. On one side, costs are determined by factor costs and productivity. Factor costs decrease and productivity increases the markup levels. The price side of the markup equation is determined by a firm's ability to influence the market price and average industry price. The firm's ability to influence the product's price is determined by the firm's market share and characteristics of an industry. The influence of market share on markups is non-linear. Market share increases a firm's ability to influence prices but in a decreasing fashion.

Additionally, organisational structure change affects both sides of the markup, namely costs and the ability to influence the selling price through product differentiation and innovation. The model applied in this research confirms that, after the cost side has been controlled for, organisational structure change additionally increases markups from the price side of the markup equation. However, this only holds when the organisational structure change is extensive enough and when it goes in a direction that increases the firm's adaptability and flexibility. The model also shows that the organisational structure change is a good indicator of firm individual effects as it indirectly identifies a firm's profile: technology, size, knowledge of employees and management style.

The influence of industry-specific factors and the macro-environment on markup decisions was not explicitly studied in the applied model. Nevertheless, ANOVA analyses show that while industry is a very influential markup determinant the macro-environment only indirectly influences firm-level markup decisions. 


\section{References}

BAIN, J. S. (1951) Relation of profit rate to industry concentration: american manufacturing, 1936-1940. Quarterly Journal of Economics, 65(3): 293-324.

BAIN, J. S. (1956) Barriers to new competition. Cambridge MA: Harvard University Press, 329.

BARNEY, J. (1991) Firm resources and sustained competitive advantage. Journal of Management, 17(1): 99-120.

BARNEY, J. and HESTERLY, W. (2006) Organizational economics: understanding the relationship between organizations and economic analysis. Clegg, S. et al., eds.: The SAGE Handbook of Organization Studies, London: SAGE Publications, 111-148.

BENNENBROEK, N. and HARRIS, R. I. D. (1995) An investigation of the determinants of profitability in New Zealand manufacturing industries in 1986-1987. Applied Economics, 27(11): 1093-1101.

BURN, T. and STALKER, G. M. (1969) Mechanistic and organic systems. J. A. Litterer, ed. Organizations: Systems, Control and Adaptation. New York: John Wiley \& Sons, 308.

BURTON, R. M. and OBEL, B. (2004): Strategic organizational diagnosis and design: the dynamics of fit. Boston: Kluwer Academic Publishers, 445.

CAVES, R. E. and PORTER, M. E. (1977) From entry barriers to mobility barriers. Quarterly Journal of Economics, 91(2): 241-262.

CHANDLER, A. D. (1962) Strategy and structure: chapters in American business history. Cambridge: The MIT Press, 463.

CHANG, S. J. (1996) An evolutionary perspective on diversification and corporate restructuring. Strategic Management Journal, 17(8): 587-611.

CLARKE, R. and DAVIES, S. W. (1982) Market structure and price-cost margins. Economica, 49(4): 277-287.

DEMSETZ, H. (1973) Industry structure, market rivalry and public policy. Journal of Law and Economics, 16(1): 1-10.

DIERICKX, I. and COOL, K. (1989) Asset stock accumulation and sustainability of competitive advantage. Management Science, 35(12): 1504-1511.

DOMOWITZ; I.; HUBBARD, G. R. and PETERSEN, B. C. (1986) Business cycles and the relationship between concentration and price cost margins. Rand Journal of Economics, 17(1): 1-17.

DRAZIN, R. and VAN DE VEN, A. H. (1985) Alternative forms of fit in contingency theory. Administrative Science Quarterly, 30(4): p. 514-539.

FEENY, S.; HARRIS, M. N. and ROGERS, M. (2005) A dynamic panel analysis of the profitability of australian tax entities. Empirical Economics, 30(1): 209-233.
GRESOV, C. (1989) Exploring fit and misfit with multiple contingencies. Administrative Science Quarterly, 34(3): 431-453.

HAY, D. and MORRIS, D. (1991) Industrial economics and organisation: theory and evidence. Oxford: Oxford University Press, 686.

JOVANOVIC, B. (1982) Selection and the evolution of industry. Econometrica, 50(3): 649-670.

KALECKI, M. (1954) Theory of economic dynamics: an essay on cyclical and long-run changes in capitalist economy. London: Allen\&Unwin, 178.

LEWIN, A. Y.; WEIGELT, C. B. and EMERY, J. D. (2004) Adaptation and selection in strategy and change, in M. S. POOLE, A. H. VAN DE VEN., eds. Handbook of Organizational Change and Innovation. Oxford: Oxford University Press, 108-160.

LIEBERMAN, M. B. and MONTGOMERY, D. B. (1998) First mover advantage. Strategic Management Journal, 9(12): 41-58.

LIPPMAN, S. A. and RUMELT, R. P. (1982) Uncertain imitability: an analysis of interfirm differences in efficiency of intercorporate ties. American Sociological Review, 13 (2): 418-438.

MACHIN, S. and VAN REENEN, J. (1993) Profit margins and the business cycle: evidence from U. K. manufacturing firms. Journal of Industrial Economics, 41(1): 29-50.

MAHONEY, J. T. and PANDIAN, J. R. (1992) The resourcebased view within the conversation of strategic management. Strategic Management Journal, 13(5): 363-380.

MARTIN, S. (1993) Advanced industrial economics. Oxford: Blackwell, 660 .

MUELLER, D. C. (1977) The persistence of profits above the norm. Economica, 44(176): 369-380.

PENROSE, E. T. (1959) The theory of the growth of the firm. New York: M. E. Sharpe, 272.

PETERAF, M. (1993) The cornerstones of competitive advantage: a resource-based view. Strategic Management Journal, 14(3): 179-191.

PETTIGREW, A. M. (1995) Longitudinal field research on change, in HUBER G. P. and VAN DE VEN, A. H., eds. Longitudinal Field Research Methods: Studying Processes of Organizational Change. Thousand Oaks: SAGE Publications, 91-125.

PORTER, M. E. (1979) The structure within industries and companies' performance. Review of Economics and Statistics, 61(2): 214-227.

ROBINS, J. and WIERSEMA, M. F. (1995) A resource-based approach to the multibusiness firm. Strategic Management Journal, 16(4): 277-299.

SCHERER, F. M. and ROSS, D. (1990) Industrial market structure and economic performance. Boston MA: Houghton Miffin, 713. 
SHARMA, A. and KESNER, I. (1996) Diversifying entry: some ex-ante explanations for postentry survival and Growth. Academy of Management Journal, 39(3): 635-677.

STALHAMMAR, N. (1991) Domestic market power and foreign trade. International Journal of Industrial Organization, 9(3): 407-424.

SCHMALENSEE, R. (1985) Do markets differ much. American Economic Review, 75(3): 341-351.
VOLBERDA, H. W. (1998) Building the flexible firm: how to remain competitive. Oxford: Oxford University Press, 349.

WHITTINGTON, R. (1993) What is strategy - and does it matter? London: International Business Press, 165.

WOODWARD, J. (2004) Industrial organization: theory and practice. London: Oxford University Press, 281. 